\title{
EARTHQUAKE STUDY IN SOUTHERN CALIFORNIA, 1944
}

\author{
B. Gutenberg and C. F. Richter \\ (Contribution No. 382, Balch Graduate School of the Geological Sciences)
}

This continues a previous report [see 1 of "References" at end of paper]. Three papers, previously named as in preparation, have now appeared $[2,3,4]$.

Study of travel-times for southern Calffornla has been rounded off by a paper on minor phases [5]. Certaln waves reflected at the 33-km level are strong over limited ranges of distance, in accordance with theoretical expectation.

Results on amplitudes are included in a more general paper [6]. The velocity of $\bar{P}$ in $\mathrm{km} / \mathrm{sec}$ is given by $v=(5.56+0.001 \mathrm{~h})$ where $\mathrm{h}$ is $\mathrm{in} \mathrm{km}$. The coefficient of $\mathrm{h}$ is a rough approximation only; It indicates increase in the bulk-modulus of elasticity by about three-quarters per cent for a pressure of 1,000 atmospheres. Simflar increases in velocity are found for the intermediate crustal layers. Below the MOHOROVIĆ IC discontinuity, velocities of $P$ and $S$ at first increase with depth, but the rate of increase falls off rapidly. Near $80 \mathrm{~km}$ the velocity decreases with depth, producing a shadow-zone of small amplitudes for $P$ and $S$. This disappears when the focus is deeper than about $250 \mathrm{~km}[13]$.

Energy-partition among reflected and refracted waves at discontinulties is given a general theoretical discussion [7] which includes many calculated numerical examples. Special values for the surface of the core [8] are used to compute amplitudes for core waves reaching the surface [9]. A theoretical study of modes of generation of seismic waves has been published [10].

To improve statistics of seismicity the magnitude scale for distant, shallow earthquakes has been revised, using observed amplitudes of surface waves [11]. These correspond closely to an absorption given by $\mathrm{k}=0.0002$ per $\mathrm{km}$ except for loss of energy in crossing the boundary of the Pacific Basin. If the path grazes the boundary as much as 90 per cent of the energy may be scattered.

To extend the magnitude scale to deep shocks it was necessary to study amplitudes of the principal phases (P, PP, S) for shallow shocks of known magnitude [12]. The absorption-coefficient for longltudinal and transverse waves in the interior of the Earth is about 0.00012 per $\mathrm{km}$. Energy leaving the focus divides about equally between longitudinal and transverse waves. Tables of amplitudes of $P, P P, S$ as functions of distance now can be used in conjunction with data on surface waves to determine magnitudes. For this purpose the reports of stations which give amplitudes for $P, P P, S$, etc., as well as of maxima, are especially valuable.

These tables and'results have been extended to deep shocks [13]. The magnitude of a deep shock is so defined as to make the energy released in two shocks of the same magnitude equal, regardless of focal depth. Magnitudes of 7-3/4 to 8 have been found throughout the range of focal depth; but during the last 40 years these seem to have been less frequent in deep' than in shallow shocks, relative to smaller magnitudes. (The greatest known shock with depth over $200 \mathrm{~km}$ was that of January 21,1906 , in Japan--magnitude 8 . The shock of May 26, 1932, at a depth of $600 \mathrm{~km}$, south of the Fij1 Islands, had a magnitude near 7-3/4.) Apparently at depths over $150 \mathrm{~km}$ only roughly one-tenth as much energy can be stored as at depths between 15 and $40 \mathrm{~km}$.

Investlgation still in progress is being partly reported in a second paper on the seismicity of the Earth [14] which includes new maps and tables of located shocks. About 70 great earthquakes have now been identified for 1904-43 and about 200 major earthquakes for 1922-43. Mechanism of Paciflc structural arcs is discussed in connection with the geographical order of the associated features and phenomena.

Compilation of as complete a catalogue of large earthquakes as is possible for the years 1904-22 is under way. A special study of earthquake activity in California includes lists of the larger recent 
shocks [15]. H. O. WOOD is preparing a study of the local epicenters thus far located, in their relation to the known fault-structure. J. M. NORDQUIST has reported on his statistical investigations [16]. A beginning has been made on study of all disturbances, large or small, recorded during a selected week. Routine bulletins covering all but the smallest local shocks, and all teleseisms recorded, have been prepared through 1944 .

\section{References}

[1] B. GUTENBERG and C. F. RICHTER, Recent results of earthquake study in Southern California, Trans. Amer. Geophys. Union, pp. 95-96, 1943.

[2] C. F. RICHTER, Calculation of small distances, Bull. Seis. Soc. Amer., v. 33, pp. 243-250, 1943.

[3] B. GUTENBERG and C. F. RICHTER, Apparent origin time of $\overline{\mathrm{S}}$, Bull. Seis. Soc. Amer., v. 33, pp. 269-279, 1943.

[4] B. GUTENBERG, Travel times of principal $P$ and $S$ phases over small distances in Southern Californla, Bull. Sels. Soc. Amer., v. 34, pp. 13-32, 1944.

[5] B. GUTENBERG, Reflected and minor phases in records of near-by earthquakes in Southern California, Bull. Sels. Soc. Amer., v. 34, pp. 137-160, 1944.

[6] B. GUTENBERG, Variations in physical properties within the earth's crustal layers, Amer. J. Sc1., Daly volume, in press.

[7] B. GUTENBERG, Energy ratio of reflected and refracted seismic waves, Bull. Seis. Soc. Amer., v. 34, pp. $85-102,1944$.

[8] S. W. DANA, The partition of energy among seismic waves reflected and refracted at the earth's core, Bull. Seis. Soc. Amer., v. 34, pp, 189-197, 1944.

[9] S. W. DANA, The amplitudes of seismic waves reflected and refracted at the earth's core, Bull. Seis. Soc. Amer., v. 35, pp. 27-35, 1945.

[10] C. Y. FU, On the origin and energy of oscillatory earthquake waves, Bull. Seis. Soc. Amer., v. 35, pp. 37-42, 1945 .

[11] B. GUTENBERG, Amplitudes of surface waves and magnitudes of shallow earthquakes, Bull. Seis. Soc. Amer., v. 35, pp. 3-12, 1945.

[12] B. GUTENBERG, Amplitudes of $P, P P$ and $S$ and magnitude of shallow earthquakes, Bull. Seis. Soc. Amer., v. 35, in press.

[13] B. GUTENBERG, Magnitude determination for deep focus earthquakes, Bull. Seis. Soc. Amer., v. 35 , in press.

[14] B. GUTENBERG and C. F. RICHTER, Seismicity of the earth (supplementary paper), Bull. Geol. Soc. Amer., in press.

[15] B. GUTENBERG and C. F. RICHTER, Frequency of earthquakes in California, Bull. Seis. Soc. Amer., v. 34, pp. 185-188, 1944.

[16] J. M. NORDQUIST, Theory of largest values applied to earthquake magnitudes, Trans. Amer. Geophys. Union, Part I, pp. 29-31, 1945.

California Institute of Technology, Pasadena, California

(Manuscript received April 27, 1945; presented by title at the Twenty-Sixth Annual Meeting, Washington, D. C., June 1, 1945; open for discussion until March 1, 1946.)

\section{BIBLIOGRAPHY}

(See also pp: 190,203, 212, 216, 240, 266, 302, and 324)

\section{BIBLIOGRAPHY: OCEANOGRAPHY}

J. A. FLEMING, H. U. SVERDRUP, C. C. ENNIS, S. L. SEATON, and W. C. HENDRIX, Scientific results of Cruise VII of the Carnegie during 1928-1929 under Command of Captain J. P. Ault: Oceanography I-B, Observations and results in physical oceanography, graphical and tabular summaries, Carnegie Inst. Wash. Pub. 525, 315 pp., 1945.

HANS PETTERSSON, Swedish oceanography during the war, Nature, v. 156, No. 3954, pp. 180-181, 1945 . 